ROCZNIK ADMINISTRACJI PUBLICZNEJ 2021 (7)

ARTYKUŁY / ARTICLES

Administracyjne prawo ustrojowe Administrative Systemic Law

PaWet OstachoWskl ${ }^{1}$

\title{
Ochrona powietrza i klimatu jako przedmiot wydatków inwestycyjnych gmin powiatu pińczowskiego
}

\section{Wprowadzenie}

Rozwijająca się polska gospodarka coraz większe nadzieje wiąże z ochroną powietrza i klimatu. Sama tylko dynamika w sektorze odnawialnych źródeł energii (OZE) w Polsce może skutkować w najbliższych latach utworzeniem blisko 77 tys. nowych miejsc pracy $^{2}$. Równie szybko transformować ma się polska energetyka, wciąż mocno oparta na „węglowym fundamencie". Wydaje się jednak, że wszystkie te procesy przebiegają zdecydowanie szybciej w regionach silniej zurbanizowanych, gdzie możliwości dochodowe mieszkańców napędzają ekologiczną koniunkturę. Łatwo dostrzec można, że gospodarstwa domowe o większych dochodach, śmielej spoglądają w stronę wykorzystania ekologicznych źródeł energii, takich jak gaz ziemny, pompy ciepła, czy fotowoltaika.

Tymczasem, na terenie mniejszych gmin wiejskich czy miejsko-wiejskich, które niemal od reformy administracyjnej z 1999 r. pozostają w końcówce rankingów rozwoju społeczno-gospodarczego, sytuacja wygląda mniej obiecująco. Wiele gmin w Polsce wciąż zamieszkałych jest przez zaledwie kilka tysięcy mieszkańców. Powoduje to, że tak ich kondycja finansowa, jak i zasoby środków budżetowych, nie pozwalają im podjąć kosztownych inwestycji w ochronę powietrza i klimatu. Dla rozwiązania tego problemu receptą wydają się być szersze rozwiązania systemowe, których niestety brakuje. Próby ratowania sytuacji wyłącznie przez wsparcie rządowe w formie dotacji celowych dla władz lokalnych, czy mieszkańców wydaje się być niewystarczające.

1 mgr Paweł Ostachowski, pracownik naukowy Instytutu Nauk o Polityce i Administracji, Uniwersytet Pedagogiczny im. Komisji Edukacji Narodowej w Krakowie.

2 Raport IEO: rozwój sektora OZE mógłby dać 77 tys. nowych miejsc pracy, https:// www.cire.pl/item,130120,1,0,0,0,0,0,raport-ieo-rozwoj-sektora-oze-moglby-dac-77 -tys-nowych-miejsc-pracy.html (dostęp: 21.02.2021). 
Ugruntowanie obecnej ilości gmin samorządowych w Polsce nie wskazuje, aby w perspektywie najbliższych lat doszło na tym szczeblu samorządu terytorialnego do procesów konsolidacyjnych, w ramach których powstaną gminy większe, zamożniejsze, z lepszymi zasobami i możliwościami finansowymi wspierania projektów ekologicznych. Liderzy lokalni, jak i społeczności gminne wydają się być zbyt mocno przywiązane do obecnego kształtu terytorialno-administracyjnego swoich małych ojczyzn, aby mogły dążyć ku jego rekonstrukcji.

Pomijając radykalne przykłady działań na rzecz ochrony powietrza i klimatu wprowadzone w Krakowie, krajobraz polskich miejscowości w okresie zimowym wciąż spowity jest dymem kopcących kominów domowych palenisk. Nie jest to bynajmniej wyraz tylko braku świadomości ekologicznej mieszkańców. Ta wydaje się systematycznie wzrastać. W wielu wypadkach jest to niestety przykład istniejącego w kraju ubóstwa energetycznego ludności, dla której koszty produkcji energii cieplnej są wciąż jednym z ważniejszych wydatków budżetu domowego. Stąd atrakcyjne cenowo paliwo $\mathrm{w}$ postaci węgla lub drewna wciąż cieszy się powodzeniem. Zupełnie nie wydają się natomiast brać tego pod uwagę obecne propozycje ekologiczne Komisji Europejskiej, których efektem mogą być nie tylko drakońskie podwyżki cen energii w Polsce, ale wręcz spadek poziomu jakości życia tysięcy Polaków.

Tymczasem, świadomość, że inwestycje w ochronę powietrza i klimatu długookresowo okazują się wyższe od poniesionych na ich rzecz nakładów wydaje się wzrastać. . Napotyka ona jednakże, tak wśród mieszkańców, jak i władz lokalnych na bariery finansowe i nierzadko bariery infrastrukturalne. Powstaje też problem sposobów i czasu dojścia do określonych celów ekologicznych. Spoglądając na coraz szybciej postępujące zmiany klimatyczne, czy groźne zjawiska pogodowe, ekoentuzjaści wskazują rok 2030 jako moment definitywnej transformacji energetycznej Europy, bez względu na jej ewentualne koszty gospodarcze i społeczne. Bardziej umiarkowani zwolennicy ochrony powietrza i klimatu dostrzegają zaś w tej dacie jedynie umowną cezurę, której nie należy traktować bezwzględnie ${ }^{4}$. Proponują mniej radykalne, bardziej wpisujące się w zasady zrównoważonego rozwoju i rozłożone w czasie działania, zmierzające do pogodzenia konieczności ochrony klimatu całej planety z zachowaniem bezpieczeństwa społecznego i rozwoju jej mieszkańców.

Celem artykułu jest odpowiedź na pytanie o stopień zaangażowania inwestycyjnego władz gmin powiatu pińczowskiego w działania na rzecz

3 Z. Wolska, Polityka Unii Europejskiej wobec zmian klimatycznych, „Studia Europejskie/Centrum Europejskie Uniwersytetu Warszawskiego” 2010, nr 3, s. 60.

4 Wystarczy tutaj spojrzeć, że pozostali najwięksi emitenci $\mathrm{CO}_{2}$ do atmosfery wcale nie spieszą się z deklarowaniem konkretnych terminów odejścia od wykorzystania paliw kopalnych w energetyce, wręcz inwestując w rozwój tego sektora w perspektywie najbliższych lat, jak choćby Chiny odpowiadające obecnie za aż $29 \%$ globalnej emisji $\mathrm{CO}_{2}$. 
ochrony powietrza i klimatu w latach 2010-2018. Przyjęte hipotezy zakładają w tym wypadku, że na terenach zamieszkałych przez małe społeczności, oddalonych od silnie nagłaśnianych w mediach obszarów o „najgorszym powietrzu”, inwestycje w ochronę powietrza i klimatu długo pozostawały poza kręgiem wydatków inwestycyjnych władz lokalnych, jak i dziś realizowane są nieśpiesznie. Powstała w efekcie takich działań skala luki inwestycyjnej w przedmiocie ochrony powietrza i klimatu, połączona z ograniczonymi zasobami własnymi gmin pińczowskich, nie pozwoli im na szybką transformację energetyczną. Utrudni to również brak dostępu dla mieszkańców do sieci dystrybucji gazu ziemnego, który choć nadal nie jest w pełni czystym paliwem, mógłby zostać narzędziem efektywnej obniżki emisji pyłów zawieszonych i $\mathrm{CO}_{2}$ na tych terenach.

Weryfikacji w/w hipotez posłużyła w tym wypadku analiza aktów prawa lokalnego odnoszących się do tworzenia gospodarki niskoemisyjnej przez władze gmin pińczowskich, jak i synteza oraz opracowanie zróżnicowanych danych pochodzących ze sprawozdań finansowych gmin oraz Banku Danych Lokalnych.

\section{Prawne i organizacyjne fundamenty ochrony powietrza i klimatu}

Fundamenty aktywności na rzecz ochrony powietrza i klimatu dostrzegamy już w Konstytucji Rzeczpospolitej Polskiej ${ }^{5}$. W przedmiocie ochrony środowiska, zobowiązuje ona każdego obywatela do jego ochrony ${ }^{6}$. Ujmując ten przepis $\mathrm{w}$ kontekście działań powodujących pogorszenie stanu środowiska, można zatem uznać, że wszyscy obywatele podejmujący się działań szkodzących powietrzu i klimatowi naruszają ustawę zasadniczą. Konstytucja Rzeczpospolitej Polskiej rozstrzyga także kwestię odpowiedzialności za środowisko, nałożoną na władze publiczne. Nakłada ona na

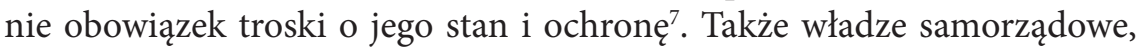
istniejące $\mathrm{w}$ trójszczeblowej strukturze są powołane do podejmowania działań chroniących obywateli i przyszłe pokolenia przed zagrożeniami wynikającymi z rozbieżności między rozwojem gospodarczym, a wymogami ochrony środowiska ${ }^{8}$.

Skoro zaś powietrze i klimat są nierozłącznymi komponentami środowiska, władze samorządu województwa, powiatu, czy gminy są zobowiązane do ich ochrony współcześnie, jak i na rzecz przyszłych pokoleń. Samorząd województwa jest $\mathrm{w}$ tym wypadku zobowiązany do prowadzenia polityki regionalnej w sposób zapewniający racjonalne korzystanie z zasobów

5 Dz. U. z 1997 r., nr 78, poz. 483.

6 Ibidem, art. 86.

7 Ibidem, art. 74.

8 R. Paczuski, Bezpieczeństwo ekologiczne jako kryterium koniecznych działań na rzecz zrównoważonego rozwoju [w:] Zrównoważony rozwój, od utopii do praw człowieka, A. Papuziński (red.), Bydgoszcz 2005, s. 120-121. 
przyrody i kształtowanie środowiska naturalnego zgodnie z zasadą zrównoważonego rozwoju'. Na władzach gminy i powiatu ciążą natomiast obowiązki ochrony środowiska traktowane bardziej bezpośrednio ${ }^{10}$. W ten sposób cała przestrzeń samorządowa w Polsce została włączona w obowiązki związane z ochroną powietrza i klimatu.

Likwidacja zagrożeń dla zdrowia i życia ludzkiego pochodzących z tej przestrzeni staje się w tym wypadku troską władz lokalnych o bezpieczeństwo ekologiczne mieszkańców ${ }^{11}$. Ono zaś nawiązuje bezpośrednio do zasady zrównoważonego rozwoju, rozumianej jako układ procesów społeczno-gospodarczych cechujący się integracją działań politycznych i społecznych w sposób pozwalający zachować równowagę przyrodniczą ${ }^{12}$. Tym samym, rozwijanie gospodarki krajowej współcześnie nie może istnieć w oderwaniu od międzynarodowej dyskusji klimatycznej. Jej celem jest zaś przeciwdziałanie działalności człowieka, która przez lata spowodowała rozchwianie równowagi przyrodniczej naszej planety.

Poszukując początków dyskusji klimatycznej w historii stosunków międzynarodowych - sięga ona końca lat 70-tych XX wieku. Jej inicjatorem stała się wówczas Organizacja Narodów Zjednoczonych (ONZ), która w ramach Programu Narodów Zjednoczonych ds. Ochrony Środowiska (UNEP) i Światowej Organizacji Meteorologicznej (WMO) powołała do życia Międzyrządowy Zespół ds. Zmian Klimatu (IPCC) ${ }^{13}$. To dzięki jego staraniom dyskusja o globalnych problemach klimatycznych przybrała format cyklicznie organizowanych „Szczytów Ziemi”. Pierwszy z nich, zwołany w Rio de Janeiro w czerwcu 1992 r., przyniósł światowej społeczności globalny program działań klimatycznych, znany szerzej jako Agenda $21^{14}$. Równie mocno w pamięci zwolenników walki o czyste powietrze i klimat zapisały się: wypracowany w 1997 r. Protokół $z$ Kioto ${ }^{15}$, będący uzupełnieniem Ramowej konwencji Narodów Zjednoczonych w sprawie

9 Art. 11 pkt. 2 ustawy z 5.06.1998 r., o samorządzie województwa, Dz. U. z 2020 r. poz. 1668.

10 Art. 4 pkt. 1 ustawy z 5.06.1998 r., o samorządzie powiatowym, Dz. U. z 2020 r. poz. 920; Art. 7 pkt. 1 ustawy z 8.03.1990 r., o samorządzie gminnym, Dz. U. z 2020 r. poz. $713,1378$.

11 P. Korzeniowski, Bezpieczeństwo ekologiczne jako instytucja prawna ochrony środowiska, Łódź 2012, s. 64.

12 E. Olejarczyk, Zasada zrównoważonego rozwoju w systemie prawa polskiego: wybrane zagadnienia, „Przegląd Prawa Ochrony Środowiska” 2016, nr 2, s. 136.

13 Międzyrządowy Zespót do spraw Zmian Klimatu Słownik ochrony środowiska, https://www.teraz-srodowisko.pl/slownik-ochrona-srodowiska/definicja/miedzyrzadowy -zespol-ds-zmian-klimatu.html (dostęp: 21.02.2021).

14 K. Czech, Szczyt Ziemi Rio +20 - Jaka przyszłość zrównoważonego rozwoju, https://www.ue.katowice. pl/fileadmin/_migrated/content_uploads/3_K.Czech_Szyt_ ziemi_rio_20...pdf (dostęp: 21.02.2021).

15 Protokół z Kioto do Ramowej Konwencji Narodów Zjednoczonych w sprawie zmian klimatu, sporządzonyw Kioto dnia 11 grudnia 1997 r., Dz. U. 2005, nr 203, poz. 1684. 
zmian klimatu ${ }^{16}$ oraz podpisane jesienią 2015 r. - Porozumienie Paryskie ${ }^{17}$. Międzynarodowej aktywności prawnej w zakresie ochrony klimatu starały się dotrzymać kroku również władze Polski. Przejście od strony formalnej do faktycznej w działaniach ochronnych utrudniał jednak dość długo brak szerszego przełożenia przyjmowanych dokumentów międzynarodowych na działania w przestrzeni lokalnej.

Protokół z Kioto formalnie rozpoczął swoje funkcjonowanie w polskim porządku prawnym w 2005 r. $^{18}$. W sektorze przedsiębiorstw i gospodarce Polski, która po czasach socjalistycznych mocno zredukowała emisje gazów i pyłów do atmosfery, przepisy protokołu dało się wypełnić jeszcze z nadwyżką ${ }^{19}$. Nie był to jednak, o tyle efekt transformacji technologicznej polskiej energetyki, co efekt likwidacji wielu gałęzi przemysłu ciężkiego, w którym zużycie energii, czy emisja gazów cieplarnianych zostały istotnie zredukowane. Ten, jakże korzystny efekt redukcji, przyniósł jednakże pewne uśpienie czujności, tak władz rządowych, jak i samorządowych. W efekcie dyskusja nad rolą społeczności lokalnych w działaniach zmierzających do ochrony powietrza i klimatu pojawiła się jednak dużo później. Dopiero rok 2015, wydaje się być tutaj przełomem, tak wskutek alarmujących informacji dotyczących stanu powietrza w Polsce, postępów ocieplenia klimatu w skali globalnej, jak i rosnących trudności polskiej gospodarki ze zmieszczeniem się w przyznanych jej limitach emisji $\mathrm{CO}_{2}$.

Ostatnie lata i miesiące przynoszą już niemal powszechną dyskusję na ten temat, zwłaszcza, że przyjęty przez Unię Europejską w grudniu $2020 \mathrm{r}$. cel redukcji $\mathrm{CO}_{2}$ o 55\% do roku 2030 nie stawia Polski w roli światowego lidera $\mathrm{w}$ walce o poprawę klimatu ${ }^{20}$. Warto $\mathrm{w}$ tym miejscu dodać, że ów cel - jakże mocno forsowany przez Komisję Europejską - nie wynika bezpośrednio z wysokości globalnej emisji $\mathrm{CO}_{2}$ przez kraje unijne, która przed wybuchem epidemii COVID-19 wyniosła ok. 10\%. W tym samym momencie Chiny, USA, Indie, Federacja Rosyjska i Japonia odpowiadały za 57\% emisji $\mathrm{CO}_{2}$ na świecie ${ }^{21}$. Pokazuje to jedynie, że radykalne działania prokli-

16 Ramowa konwencja Narodów Zjednoczonych w sprawie zmian klimatu, sporzadzona w Nowym Jorku dnia 9 maja 1992 r., Dz. U. 1996, nr 53, poz. 238.

17 Dz. U. 2017, poz. 36.

18 Mechanizm wejścia w życie Protokołu z Kioto zakładał spełnienie zasady „2 $\times 55$ ”, a więc ratyfikować musiało go min. 55 krajów świata, wytwarzających minimum $55 \%$ globalnych emisji $\mathrm{CO}_{2}$.

19 A. Kassenberg, M. Sobolewski, Zmiany klimatu: polityka i działania na rzecz ograniczenia emisji gazów szklarniowych $w$ Unii Europejskiej $i w$ Polsce, Polski Klub Ekologiczny - Okręg Mazowiecki, Warszawa 2002, s. 30-32.

20 M. Józefiak, Pięć lat po porozumieniu paryskim: sześć wyzwań dla Polski, https:// energia.rp.pl/smog/klimat/ 27353-piec-lat-po-porozumieniu-paryskim-szesc-wyzwan -dla-polski (dostęp: 21.02.2021).

21 Udział poszczególnych emisji krajów w globalnej emisji $\mathrm{CO}_{2}$ wyniósł tu odpowiednio 29\% (Chiny), 14\% (USA), 7\% (Indie), 4\% (Federacja Rosyjska), 3\% (Japonia); Najwięksi emitenci $\mathrm{CO}_{2}$ - przegląd, https://naukaoklimacie.pl/aktualnosci/najwieksi -emitenci-co2-przeglad-431 (dostęp: 11.08.2021). 
matyczne na terenie Unii Europejskiej, nie są w stanie wpłynąć na globalne zmiany klimatyczne w sposób wystarczająco silny, bez zaangażowania w podobne procesy ze strony głównych globalnych emitentów dwutlenku węgla. Co więcej, działalność Komisji Europejskiej, która planuje w ramach programu „Fit for 55” obejmować kolejne branże - po energetyce - systemem handlu uprawnieniami do emisji, staje się wręcz niebezpieczna dla gospodarek krajów takich jak Polska, które czeka skokowy wzrost kosztów wytwarzania produktów i usług, a co za tym idzie podniesienie finalnych cen dla konsumentów ${ }^{22}$.

Także w Polsce, radykalne obniżenie całkowitej emisji $\mathrm{CO}_{2}$, zgodnie z propozycjami Komisji Europejskiej grozić może skokowym wzrostem cen energii, jak i produktów oraz usług, w szczególności tych objętych proponowanymi mechanizmami handlu emisjami $\mathrm{CO}_{2}$. Już teraz, podejmowanie działań zmierzających do wdrażania rozwiązań ekologicznych, chroniących powietrze i klimat jest mocno utrudnione w wielu samorządach, nie mówiąc już o proponowanych przez Brukselę rozwiązaniach.

Dotychczasowe efekty działań polskich gmin w przedmiocie ochrony powietrza i klimatu, w większości przypadków są również mocno dyskusyjne. Ograniczone dochody własne gmin skutkują nadal zbyt często marginalizacją lub pomijaniem kwestii klimatycznej w polityce lokalnej. Tymczasem promowanie transportu publicznego opartego o wykorzystanie elektryczności czy CNG, termomodernizacja budynków publicznych, czy wspieranie mieszkańców we wdrażaniu OZE lub gazu ziemnego do ogrzewania budynków są inwestycjami w czyste powietrze i klimat.

Wizja zmniejszenia strumienia funduszy europejskich dla polskich gmin niepodejmujących planowanej aktywności na rzecz transformacji energetycznej, spowodowała w ostatnich latach pojawienie się planów gospodarki niskoemisyjnej. Wydają się one być trafnym krokiem w kierunku bardziej aktywnej polityki inwestycyjnej gmin, chroniącej powietrze i klimat. Pokazują one skalę istniejących i narastających przez lata zaniedbań władz lokalnych w tym zakresie gruntownie systematyzują i porządkują również działania gmin, zmierzające do zmiany zastanego stanu rzeczy. Problemem pozostaje jednak ich spójność z lokalną polityką inwestycyjną, która wydaje się nie być wystarczająca ${ }^{23}$.

\section{Inwestycje polskich gmin a ochrona powietrza i klimatu}

Problem z wdrażaniem planów gospodarki niskoemisyjnej, przyjmowanych przez polskie gminy wydaje się mieć zróżnicowane podłoże. Trudno

22 UE planuje wprowadzić uprawnienia do emisji $\mathrm{CO}_{2}$ dla transportu i budownictwa, https://www.energetyka24.com/ue-planuje-wprowadzic-uprawnienia-do-emisji-co2 -dla-transportu-i-budownictwa-komentarz (dostęp: 11.08.2021).

23 A. Szafrański, Prawo energetyczne. Wartości i instrumenty ich realizacji, Warszawa 2014 , s. 215. 
uznać je za dokumenty, których obowiązek pełnej realizacji wynika z jakichkolwiek przepisów prawa krajowego. Przyjmują one co prawda formę uchwały organu stanowiącego gminy, jednak próżno szukać w nich jakichkolwiek sankcji prawnych na wypadek niezrealizowania ich postanowień. Tym samym plany te, podobnie jak strategie rozwoju lokalnego, są tak szczególną kategorią dokumentów, że ich moc obowiązującą, jak i restrykcje dotyczące realizacji wyznacza zwykle sam ich twórca. Ten zaś, zachowując dla siebie margines bezpieczeństwa, rzadko decyduje się nakładać na siebie sankcje związane $\mathrm{z}$ ich niewykonaniem ${ }^{24}$. Stąd też plany gospodarki niskoemisyjnej, niejednokrotnie wyznaczają albo ambitne cele, których realizacja wydaje się niemal nierealna, albo też niezwykle zachowawcze, których wykonanie jedynie utwierdza lokalną społeczność w błędnym przekonaniu i skuteczności rządzenia ich lokalnych władz.

Jedną z kwestii słabo akcentowanych w tego typu dokumentach, wydają się być działania na rzecz elektromobilności, czy promowania publicznego transportu niskoemisyjnego. Tymczasem z $400 \mathrm{mln}$ ton $\mathrm{CO}_{2}$ wyemitowanych w Polsce w 2018 r., aż 65 mln pochodziło z transportu ${ }^{25}$. Ekspansja „starej” motoryzacji w polskich wsiach i miasteczkach wydaje się rozszerzać, przy bierności, a często wręcz zadowoleniu władz lokalnych, które pozbywają się $\mathrm{w}$ ten sposób części kosztów organizacji transportu lokalnego, przenosząc ją na mieszkańców. Zahamowanie tego zjawiska wydaje się natomiast koniecznością najbliższej dekady. W tym wypadku, nie tyle chodzi o zmuszenie mieszkańców do rezygnacji z własnych samochodów jako środka transportu, co stworzenie dla nich skutecznej i tańszej alternatywy w postaci sprawnej komunikacji lokalnej, wykorzystującej do zasilania gaz ziemny, bądź energię elektryczną. Podobnie rzecz się ma z intensywną hodowlą zwierząt, odpowiadającą za emisję ponad $33 \mathrm{mln}$ ton $\mathrm{CO}_{2}$ w skali całego kraju. Troska o rozwój gospodarczy obszarów wiejskich ze strony władz lokalnych, także w tym wypadku niejednokrotnie wygrywa $z$ ochroną powietrza i klimatu. Dużo wolniej upowszechniają się natomiast $\mathrm{w}$ tym sektorze rozwiązania zmierzające do zagospodarowania powstających w wyniku hodowli produktów ubocznych, jak choćby biogazu do wytwarzania w gospodarstwach rolnych ${ }^{26}$.

Brak gwarancji szerszego wsparcia rządowego dla samorządów planujących w ramach swojej lokalnej gospodarki ambitną działalność na rzecz ochrony powietrza i klimatu, wydaje się być problemem koniecznym do pokonania w najbliższych latach. Widać to dobrze zwłaszcza na przykładzie

24 E. Ochendowski, Prawo administracyjne. Część ogólna, Toruń 2006, s. 141-142.

25 Emisja dwutlenku węgla w ciągu ostatnich 30 lat wzrosła niemal trzykrotnie; M. Józefiak, Pięć lat po porozumieniu paryskim: sześć wyzwań dla Polski, https://energia .rp.pl/smog/klimat/ 27353-piec-lat-po-porozumieniu-paryskim-szesc-wyzwan-dla-polski (dostęp: 21.02.2021).

26 M. Czop, E. Kłapcia, Zagospodarowanie odchodów trzody chlewnej z wybranej fermy do celów energetycznych, „Inżynieria i Ochrona Środowiska” 2017, 20(1), s. 7. 
niewielkich gmin wiejskich i miejsko-wiejskich, gdzie rozproszona zabudowa, czy ograniczone dochody mieszkańców powodują dla władz lokalnych trudności $w$ realizacji inwestycji lokalnych sprzyjających ochronie powietrza i klimatu. Dotkliwy wydaje się również brak dostępu mieszkańców niektórych gmin do gazu ziemnego, bez którego szybka transformacja polskiego ciepłownictwa, odpowiadającego za emisję pyłów zawieszonych oraz ok. $70 \mathrm{mln}$ ton $\mathrm{CO}_{2} \mathrm{w}$ skali roku także okaże się trudna.

Tymczasem oświata, transport, czy ochrona zdrowia od lat pochłaniają większość funduszy polskich gmin, pozostawiając niewiele środków na inwestycje klimatyczne. Tym bardziej władze centralne powinny dołożyć starań, aby poznać bariery hamujące lokalne inwestycje samorządowe służące ochronie powietrza i klimatu. Konieczne wydaje się wręcz stworzenie nowych rozwiązań prawnych, umożliwiających gminom w większym stopniu samodzielne pozyskiwanie funduszy na transformację energetyczną, nie tylko ze środków będących w dyspozycji władz centralnych, ale i tych pochodzących z zagranicy. Do tego potrzebna jest jednak ich lepsza kondycja finansowa, jak i większe zasoby własne gmin, które w ostatnich latach, mimo dość szerokiego strumienia dotacji rządowych, wydają się kurczyć.

\section{Wydatki na ochronę powietrza i klimatu w powiecie pińczowskim}

Wyżej wskazane wyzwania dotyczące działalności polskich gmin, związane z ochroną powietrza i klimatu, najlepiej ilustruje wycinek lokalnej rzeczywistości samorządowej. Jako studium przypadku posłużą tutaj gminy powiatu pińczowskiego. Położony jest on w południowej części województwa świętokrzyskiego, w dolinie rzeki Nidy, a jego obszar wchodzi w skład makroregionu Niecki Nidziańskiej stanowiącej rozległe obniżenia pomiędzy Wyżyną Krakowsko-Częstochowską, a Kielecko-Sandomierską ${ }^{27}$.

Prowadzone przez Państwową Inspekcję Ochrony Środowiska i Wojewódzki Inspektorat Ochrony Środowiska w Kielcach badania jakości powietrza w tym subregionie wskazują, że stężenia roczne dwutlenku siarki i dwutlenku azotu, nie przekraczają połowy dopuszczalnej normy. Te same dane wskazują jednocześnie, że zanieczyszczenia pyłem zawieszonym, pochodzące z procesów spalania paliw, źle zagospodarowanych hałd i składowisk wymagają już jednak działań zapobiegawczych ${ }^{28}$. Subregion pińczowski graniczy na północy z powiatami kieleckim, buskim, kazimierskim i jędrzejowskim, oraz powiatem miechowskim wchodzącym w skład województwa małopolskiego. Obecnie w jego granicach leży pięć gmin: Pińczów, Działoszyce, Złota, Michałów i Kije. Największą pozostaje miejsko-wiejski Pińczów będący centrum administracyjnym powiatu. Prócz

27 Strategia rozwoju powiatu pińczowskiego, Pińczów 2015, s. 5.

28 Ibidem, s. 7. 
niego, jedynie Działoszyce posiadają prawa miejskie ${ }^{29}$. Zróżnicowanie gospodarcze i demograficzne gmin powiatu prezentuje tabela 1.

Tabela 1. Gminy powiatu pińczowskiego - demografia i aktywność gospodarcza

\begin{tabular}{|l|c|c|c|c|c|}
\hline \multirow{2}{*}{ Gmina } & \multirow{2}{*}{$\begin{array}{c}\text { Powierzchnia } \\
\mathbf{k m}^{2}\end{array}$} & \multicolumn{2}{c|}{$\begin{array}{c}\text { Ludność wg miejsca } \\
\text { zamieszkania }\end{array}$} & \multicolumn{2}{c|}{$\begin{array}{c}\text { Podmioty sektora } \\
\text { prywatnego }\end{array}$} \\
\cline { 3 - 6 } & 106 & 5380 & 4958 & 230 & 266 \\
\hline Działoszyce & 100 & 4546 & 4415 & 184 & 248 \\
\hline Kije & 112 & 4831 & 4606 & 206 & 224 \\
\hline Michałów & 213 & 21869 & 20831 & 1491 & 1501 \\
\hline Pińczów & 82 & 4804 & 4461 & 217 & 250 \\
\hline Złota & 613 & 41430 & 39271 & 2328 & 2489 \\
\hline POWIAT & & & & & 2010 \\
\hline
\end{tabular}

Źródło: opracowanie własne na podstawie informacji z Urzędu Statystycznego w Kielcach.

Na podstawie danych zawartych w tabeli 1 dostrzegamy, że cztery gminy powiatu tworzyły niewielkie społeczności lokalne. Widać jednocześnie, że największe skupisko ludności znajdowało się na terenie gminy Pińczów, gdzie na koniec 2018 r., zamieszkiwało ponad 53\% mieszkańców powiatu. Cały jego teren w latach 20102018 był dotknięty zjawiskiem depopulacji ludności, czyli procesem systematycznego i trwałego ubytku liczby mieszkańców ${ }^{30}$. Zjawisko to w dłuższej perspektywie czasu powoduje zaś zmiany w strukturze ludności, jak i jej zatrudnienia i dochodów, które w konsekwencji wpływają też na poziom zasobów samorządowych oraz przemiany w jej lokalnej polityce gospodarczej i społecznej ${ }^{31}$.

Najsilniej spadek liczby mieszkańców odczuł Pińczów, którego zaludnienie spadło wówczas o 1038 osób ${ }^{32}$. Mniejsze, choć równie istotne zmiany ludnościowe zanotowały gminy Działoszyce, Złota, Michałów i Kije. Wzrastała natomiast aktywność sektora prywatnego. Na 161 nowych podmiotów wpisanych do KRS, najwięcej pojawiło się w Kijach, Działoszycach oraz Złotej. Pozwala to zatem sądzić, że procesy depopulacyjne w powiecie, nie spowodowały regresu aktywności gospodarczej na tym terenie.

Spoglądając na wydatki gmin powiatu pińczowskiego przeznaczone na ochronę powietrza i klimatu jedynie gmina Kije (poza 2012 r.)

29 Statystyczne vademecum samorzadowca-powiat pińczowskiw 2019 roku, https:// kielce.stat.gov.pl/vademecum/vademecum_swietokrzyskie/portrety_powiatow/ Powiat\%20 pinczowski.pdf (dostęp: 21.02.2021).

30 J. Hrynkiewicz, Depopulacja wyzwaniem polityki ludnościowej [w:] Depopulacja. Uwarunkowania i konsekwencje, J. Hrynkiewicz, G. Ślusarz (red.), GUS, Warszawa 2020, s. 19.

31 J. Hrynkiewicz, op. cit., s.20.

32 Liczba ludności w gminie, w ciągu 9 lat skurczyła się zatem o 4,75\%. Stanowiło to jednocześnie ponad $48 \%$ ubytku mieszkańców w skali całego powiatu. 
systematycznie w latach 2010-2018 przeznaczała część swoich wydatków budżetowych na inwestycje tego rodzaju. Władze Pińczowa rozpoczęly takie działania od 2013 r., Złotej - od 2015 r., a Działoszyc dopiero w 2017 r. Niektóre z podjętych zadań nie były zatem bezpośrednio związane z pojawieniem się w gminach powiatu planów gospodarki niskoemisyjnej, lecz zostały rozpoczęte wcześniej. Sam proces tworzenia tych dokumentów rozpoczął się w 2015 r., skończył zaś w maju 2017 r. Pierwszy taki dokument uchwalili radni Pińczowa ${ }^{33}$. Kolejno podobne uchwały podjęły władze Michałowa $^{34}$, Działoszyc ${ }^{35}$, Kijów ${ }^{36}$ iZłotej $^{37}$. Analiza tych dokumentów wskazuje na dość zachowawcze określenie celów lokalnej polityki klimatycznej, tak pod względem stawianych w nich do osiągnięcia poziomów redukcji gazów cieplarnianych, jak i kroków zmierzających do przyspieszenia transformacji energetycznej. W planach poświęcono także nieco uwagi źródłom finansowania planowanych zadań. Przełożenie ich na wydatki inwestycyjne okazało się jednak dyskusyjne, na co wskazują dane przedstawione w tabeli 2.

Wydatki prezentowane w tabeli powyżej wskazują liderów w przedmiocie ich realizacji. Najwięcej funduszy lokalnych na w/w działania przeznaczyły władze Pińczowa. Ich realizacja przypadła tutaj na lata 2013-2018. Dane te potwierdzają jednocześnie hipotezę o istniejącym już wówczas rozdźwięku między inwestycjami w ochronę powietrza i klimatu, a planistyczną działalnością władz lokalnych w tym zakresie. Gmina Michałów, mimo wyznaczenia sobie celów w przedmiocie transformacji energetycznej jesienią 2016 r., do końca analizowanego okresu nie dokonała żadnych wydatków inwestycyjnych chroniących powietrze i klimat. Tymczasem władze Złotej, mimo przyjęcia własnego planu gospodarki niskoemisyjnej dopiero w maju 2017 r., zdołały do końca 2018 r. wydać na ochronę

33 Uchwała Nr XXV/209/2016 Rady Miejskiej w Pińczowie z dnia 26.10.2016 r., w sprawie przyjęcia do realizacji Planu Gospodarki Niskoemisyjnej dla Gminy Pińczów, oraz Aneks nr 1 do Planu Gospodarki Niskoemisyjnej dla Gminy Pińczów przyjęty uchwałą nrXXXVI/321/2017 Rady Miejskiej w Pińczowie z dnia 11.10.2017 r., http://bip.gminy.com.pl/pinczow/pliki/01_Studium_ustalenia_tekstowe.pdf (dostęp: 21.02.2021).

34 Uchwała Nr XXVII/157/2016 Rady Gminy Michałów z dnia 25.11.2016 r., w sprawie przyjęcia Planu Gospodarki Niskoemisyjnej dla Gminy Michałów, https://michalow.bip.gov.pl/uchwaly-2016r/sesja-z-dnia-25-listopada-2016-roku.html (dostęp: 21.02.2021).

35 Uchwała Nr XXXIII/153/2016 Rady Miejskiej w Działoszycach z dnia 21.12.2016 r., w sprawie przyjęcia Planu Gospodarki Niskoemisyjnej dla Gminy Działoszyce na lata 2016-2020, http://dzialoszyce.eobip.pl/_gAllery/60/88/6088/Uchwala_Nr_XXXIII-153-2016.pdf (dostęp: 21.02.2021).

36 Uchwała Nr XXVI/226/17 Rady Gminy Kije z dnia 10.05.2017 r., w sprawie przyjęcia Planu Gospodarki Niskoemisyjnej dla Gminy Kije, http://kije.biuletyn.net/fls/ bip_pliki/2020_08/BIPOLD003662/3662.pdf (dostęp: 21.02.2021).

37 Uchwała Nr XXIII/168/2017 Rady Gminy Złota z dnia 30.05.2017 r., w sprawie przyjęcia Planu Gospodarki Niskoemisyjnej dla Gminy Złota, Załącznik 1, http://bip

.gminazlota.pl/pliki/pgn_dla_gminy\%20zlota.pdf (dostęp: 21.02.2021). 


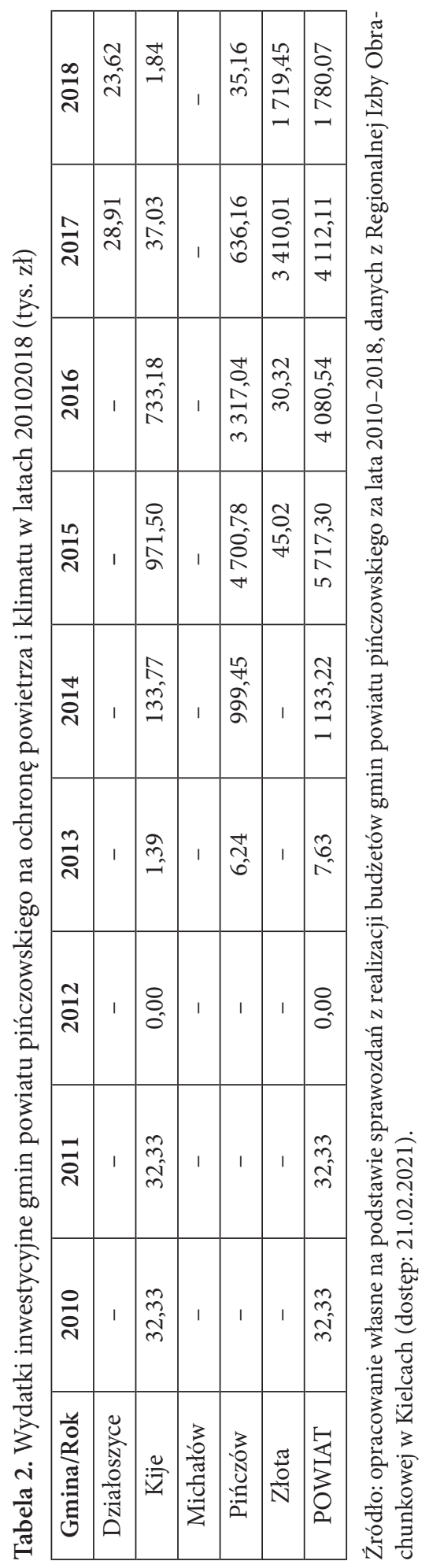


powietrza i klimatu kwotę ponad 5,2 mln zł. Przykład Złotej i Michałowa, a więc dwóch jakże niewielkich gmin, niemal sąsiadujących ze sobą, pokazuje, że hipoteza o słabości działań inwestycyjnych małych samorządów $\mathrm{w}$ przedmiocie ochrony powietrza i klimatu wskutek ich słabej kondycji finansowej, czy ograniczonych zasobów nie zawsze zdaje się sprawdzać. To od podejścia władz lokalnych do tej problematyki, jak i umiejętności oraz determinacji w poszukiwaniu środków na wsparcie inwestycji klimatycznych, zależą w dużej mierze ich sukcesy.

W skali powiatu widoczny wzrost wydatków inwestycyjnych gmin na ochronę powietrza i klimatu nastąpił po 2014 r. Ich zróżnicowany rozkład prezentuje tabela 3 .

Tabela 3. Rozkład wydatków inwestycyjnych gmin powiatu pińczowskiego na ochronę powietrza i klimatu w latach 2010-2018 (\%)

\begin{tabular}{|c|c|c|c|c|c|c|c|c|c|}
\hline $\begin{array}{c}\text { Gmina/ } \\
\text { Rok }\end{array}$ & 2010 & 2011 & 2012 & 2013 & 2014 & 2015 & 2016 & 2017 & 2018 \\
\hline Działoszyce & - & - & - & - & - & - & - & 0,70 & 1,33 \\
\hline Kije & 100 & 100 & - & 18,22 & 11,80 & 16,99 & 17,97 & 0,90 & 0,10 \\
\hline Michałów & - & - & - & - & - & - & - & - & - \\
\hline Pińczów & - & - & - & 81,78 & 88,20 & 82,22 & 81,29 & 15,47 & 1,98 \\
\hline Złota & - & - & - & - & - & 0,79 & 0,74 & 82,93 & 96,59 \\
\hline
\end{tabular}

Źródło: opracowanie własne na podstawie danych z tabeli 2.

Dane w tabeli 3 potwierdzają, że największy strumień funduszy na inwestycje służące ochronie powietrza i klimatu w powiecie pińczowskim był efektem działań gmin Pińczów oraz Złota. Oba samorządy okazały się liderami wydatków inwestycyjnych tego rodzaju w badanym okresie. Trzecia w aktywności tego rodzaju znalazła się gmina Kije. Dokładniejszy rozkład wydatków tego rodzaju ilustruje wykres 1 .

Dominacja gmin Pińczów i Złota w wydatkach inwestycyjnych na ochronę powietrza nie ulega wątpliwości. Obie jednostki w latach 20102018 odpowiadały za $88,19 \%$ transferów tego rodzaju w skali powiatu. Niemniej, ogólna suma wydatków inwestycyjnych wszystkich gmin powiatu per capita w latach 2010-2018 wyglądała nieco inaczej. Ilustruje ją wykres 2.

Wykres 2 ilustruje, że nakłady inwestycyjne gmin powiatu pińczowskiego per capita na ochronę powietrza i klimatu w latach 2010-2018 okazały się skromne. W ciągu 9 lat, żadna $\mathrm{z}$ gmin nie wydała na ten cel więcej niż 120 zł na mieszkańca. Dla porównania warto wskazać położoną w sąsiednim powiecie gminę Busko Zdrój, gdzie wydatki samego rodzaju na jednego mieszkańca wyniosły niemal 1243,89 zł. Liderem okazała się tutaj gmina Złota, gdzie skala inwestycji, skorelowana z niewielką liczbą mieszkańców pozwoliła uzyskać dobry wynik. 
Wykres 1. Rozkład wydatków inwestycyjnych na ochronę powietrza i klimatu w powiecie pińczowskim w latach 2010-2018 (\%)

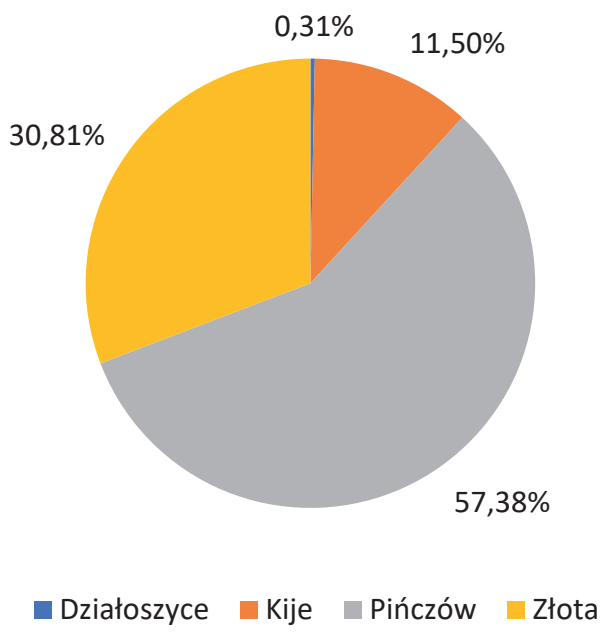

Źródło: opracowanie własne na podstawie tabeli 2.

Wykres 2. Wydatki inwestycyjne gmin powiatu pińczowskiego na ochronę powietrza i klimatu per capita w latach 2010-2018 (zł)

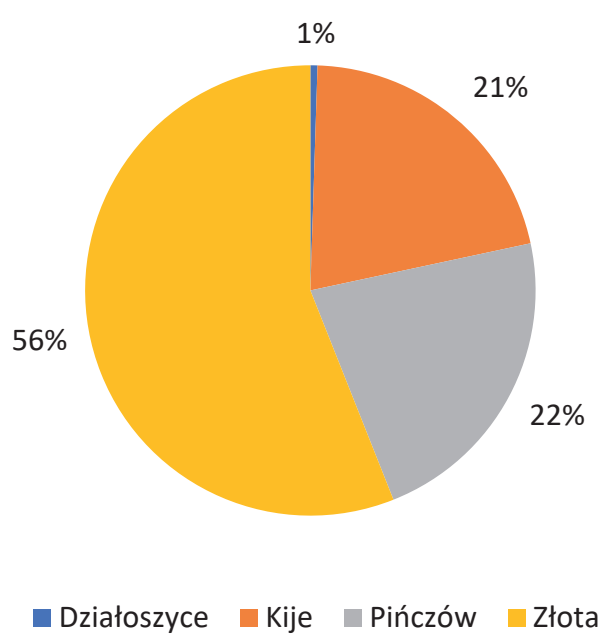

Źródło: opracowanie własne na podstawie tabel 1 i 2. 
Wciąż ograniczone wydatki inwestycyjne władz gminnych na ochronę powietrza i klimatu w powiecie pińczowskim wydają się nie być jednak jedynym problemem transformacji energetycznej tego terenu. Jej hamulcem mogą okazać się też istniejące braki w sieci dystrybucyjnej gazu ziemnego, uniemożliwiające wykorzystanie tego paliwa przez mieszkańców poszczególnych gmin do celów grzewczych. Wysiłki władz lokalnych próbujące zniwelować ów brak promowaniem OZE, mogą zaś okazać się tutaj niewystarczające, zwłaszcza podczas surowych zim, kiedy to potrzeby energetyczne gospodarstw domowych zwykle mocno przekraczają możliwości produkcyjne przydomowej fotowoltaiki.

Brak możliwości skorzystania w takiej sytuacji z chroniącej jakość powietrza energii „błękitnego paliwa” wydaje się być problemem koniecznym do rozwiązania w najbliższych latach. Poziom wykorzystania gazu ziemnego przez mieszkańców powiatu pińczowskiego wypada bowiem szczególnie słabo, na co wskazują informacje zawarte w tabeli 4 .

Tabela 4. Wykorzystanie gazu ziemnego przez mieszkańców powiatu pińczowskiego w latach 2010-2018 (\%)

\begin{tabular}{|c|c|c|c|c|c|c|c|c|c|}
\hline $\begin{array}{c}\text { Gmina/ } \\
\text { Rok }\end{array}$ & 2010 & 2011 & 2012 & 2013 & 2014 & 2015 & 2016 & 2017 & 2018 \\
\hline Działoszyce & - & - & - & - & - & - & - & - & - \\
\hline Kije & - & - & - & - & - & - & 0,1 & 0,1 & 0,1 \\
\hline Michałów & - & - & - & - & - & - & - & - & - \\
\hline $\begin{array}{c}\text { Pińczów } \\
(\mathrm{m})\end{array}$ & 0,6 & 0,9 & 1,3 & 1,5 & 1,9 & 2,3 & 2,6 & 2,9 & 3,5 \\
\hline $\begin{array}{c}\text { Pińczów } \\
(\mathrm{w})\end{array}$ & 0,1 & 0,2 & 0,2 & 0,3 & 0,4 & 0,5 & 0,5 & 0,6 & 0,9 \\
\hline Złota & - & - & - & - & - & - & - & - & - \\
\hline POWIAT & 0,3 & 0,5 & 0,7 & 0,8 & 1,0 & 1,2 & 1,4 & 1,5 & 1,9 \\
\hline
\end{tabular}

(m) - miasto, (w) - obszar wiejski, Źródło: opracowanie własne na podstawie Banku Danych Lokalnych, https://bdl.stat.govh.pl/BDL/dane/podgrup/teryt (dostęp: 21.02.2021).

Dane z tabeli 4 potwierdzają, że poziom wykorzystania gazu ziemnego przez mieszkańców gmin powiatu pińczowskiego do końca 2018 r. pozostawał niewielki. Tysiące z nich wciąż nie wykorzystywało tego źródła energii do celów gospodarczych. Jego dostępność była niska także w miastach. Nawet w Pińczowie, zamieszkałym pod koniec 2018 r., przez ponad $27 \%$ ludności powiatu, wykorzystywało go zaledwie 3,5\% mieszkańców. Pokazuje to ogromny, wciąż niewykorzystany potencjał zastosowania tego paliwa w procesach transformacji energetycznej tego terenu. Niestety, duża $\mathrm{w}$ tym zasługa powolnie postępującej gazyfikacji na terenie województwa 
świętokrzyskiego, dla której nawet perspektywa do 2030 r., nie zakłada zakończenia procesów gazyfikacyjnych dla wszystkich gmin.

\section{Wnioski}

Ochrona powietrza i klimatu w Polsce oraz towarzysząca jej transformacja energetyczna w skali lokalnej napotykają na trudności. Samorządowcom brakuje środków finansowych na kosztowne inwestycje klimatyczne oraz zdecydowania w podejmowaniu działań na rzecz realizacji celów przyjmowanych we własnych planach gospodarki niskoemisyjnej. Niewiele wciąż jest działań na rzecz promowania elektromobilności, czy niskoemisyjnego transportu publicznego. Efektem jest zaś coraz silniej zatruwająca polskie lokalne powietrze motoryzacja, w której władze lokalne widzą raczej oznakę rosnącej zamożności mieszkańców niż przyszłej katastrofy klimatycznej. Brakuje tutaj szczególnie rozwiązań wykorzystujących już dostępne dla wielu gmin narzędzia zachęcające mieszkańców do korzystania z transportu publicznego. Równie rzadko władze lokalne wyznaczają konkretne terminy odchodzenia gospodarstw domowych od spalania węgla, choć w tym wypadku trudniej o tego typu uchwały władz lokalnych, zwłaszcza że wiele małych gmin wciąż dla węgla, czy drewna używa alternatywy w postaci gazu ziemnego.

Wydaje się, że także władze centralne do końca nie mogą się zdecydować, w jaki sposób przyspieszyć transformację energetyczną w przestrzeni lokalnej. Z jednej strony proponują one mieszkańcom coraz bardziej zróżnicowane formy wsparcia finansowego na budowę instalacji wykorzystujących OZE. Z drugiej strony, zachowawczo podchodzą do zapewnienia samorządom dodatkowych źródeł dochodów własnych, które mogłyby służyć konkretnie celom klimatycznym. Od lat system dochodów własnych samorządów, ustalony jeszcze ustawą z 2003 r. wydaje się bowiem słabnąć, padając ofiarą choćby niedawnych obniżek podatków dochodowych od osób fizycznych i prawnych, bez jednoczesnej korekty udziału samorządów $\mathrm{w}$ dochodach podatkowych tego rodzaju.

Także same gminy wydają się wciąż kroczyć nieco po omacku ścieżką lokalnej polityki klimatycznej. Nieufnie podchodzą do współpracy między sobą w tym zakresie. Ta zaś mogłaby stworzyć i wdrożyć o wiele bardziej ambitne projekty chroniące powietrze i klimat, aniżeli te inicjowane indywidualnie. Analizowany przypadek pięciu gmin powiatu pińczowskiego potwierdza ostatni wniosek. Pokazuje również, że organizacja polityki ochrony powietrza i klimatu dla władz lokalnych tego powiatu w latach 2010-2018 okazała się zadaniem nierzadko marginalizowanym inwestycyjnie. Owszem, część niepowodzeń gmin w tej kwestii można by uzasadnić ich słabą kondycją finansową, jak i poziomem dochodów własnych. Tym niemniej, nie należy $\mathrm{w}$ tym miejscu ignorować niezbyt aktywnej postawy 
władz lokalnych, których umiejętności poszukiwania środków na inwestycje służące ochronie powietrza i klimatu okazały się niewystarczające.

Próbując wskazać rekomendację dla gmin powiatu pińczowskiego $\mathrm{w}$ przedmiocie ochrony powietrza i klimatu na najbliższe lata, konieczne wydaje się wprowadzenie co najmniej regularności przeznaczania funduszy na cele klimatyczne. Najlepiej, aby przyjęła ona formę limitu wydatków inwestycyjnych, których realizacja byłaby obligatoryjna. Dzięki temu zniknąć mogłaby istniejąca dotychczas symboliczność wspierania polityki klimatycznej z budżetów gminnych kwotami nieprzekraczającymi kilku tysięcy zł. Cel ten wydaje się wcale nieodległy do osiągnięcia, jeśli tylko pojawi się dla niego zrozumienie wśród władz lokalnych. Jak na razie, wszelkie tego rodzaju próby wiązania funduszy inwestycyjnych z ochroną powietrza i klimatu nie cieszą się jednak popularnością w skali kraju. Więcej za to głosów krytyki ze strony samorządowców kierowanych wobec władz centralnych, przy jednocześnie, jakże wciąż rzadkich aktywnych działaniach własnych w tej kwestii, na które już teraz pozwala prawo krajowe.

\section{Bibliografia}

Czech K., Szczyt Ziemi Rio +20 - Jaka przyszłość zrównoważonego rozwoju, https:// www.ue.katowice.pl/fileadmin/_migrated/content_uploads/3_K.Czech_Szyt_ ziemi_rio_20....pdf (dostęp: 21.02.2021).

Czop M., Kłapcia E., Zagospodarowanie odchodów trzody chlewnej z wybranej fermy do celów energetycznych, „Inżynieria i Ochrona Środowiska” 2017, nr 20(1).

Hrynkiewicz J., Depopulacja wyzwaniem polityki ludnościowej, [w:] Depopulacja. Uwarunkowania i konsekwencje, J. Hrynkiewicz, G. Ślusarz (red.), GUS, Warszawa 2020.

Józefiak M., Pięć lat po porozumieniu paryskim: sześć wyzwań dla Polski, https:// energia.rp.pl/smog/klimat/ 27353-piec-lat-po-porozumieniu-paryskim-szesc -wyzwan-dla-polski (dostęp: 21.02.2021).

Kassenberg A., Sobolewski M., Zmiany klimatu: polityka i działania na rzecz ograniczenia emisji gazów szklarniowych w Unii Europejskiej i w Polsce, Polski Klub Ekologiczny - Okręg Mazowiecki, Warszawa 2002.

Konstytucja Rzeczypospolitej Polskiej z 2 kwietnia 1997 r., Dz. U. z 1997 r., nr 78, poz. 483.

Korzeniowski P., Bezpieczeństwo ekologiczne jako instytucja prawna ochrony środowiska, Łódź 2012.

Międzyrzadowy Zespół do spraw Zmian Klimatu - Słownik ochrony środowiska, https://www.teraz-srodowisko.pl/slownik-ochrona-srodowiska/definicja/ miedzyrzadowy-zespol-ds-zmian-klimatu.html (dostęp: 21.02.2021).

Najwięksiemitenci $\mathrm{CO}_{2}$ - przeglad, https://naukaoklimacie.pl/aktualnosci/najwieksi -emitenci-co2-przeglad-431 (dostęp: 11.08.2021).

Ochendowski E., Prawo administracyjne. Część ogólna, Torun 2006.

Olejarczyk E., Zasada zrównoważonego rozwoju w systemie prawa polskiego: wybrane zagadnienia, „Przegląd Prawa Ochrony Środowiska” 2016, nr 2. 
Paczuski R., Bezpieczeństwo ekologiczne jako kryterium koniecznych działań na rzecz zrównoważonego rozwoju [w:] A. Papuziński (red.), Bydgoszcz 2005.

Porozumienie paryskie do Ramowej Konwencji Narodów Zjednoczonych w sprawie zmian klimatu, sporzadzonej w Nowym Yorku dnia 9 maja 1992 r., przyjęte w Paryżu dnia 12 grudnia 2015 r., Dz. U. 2017, poz. 36.

Protokół $z$ Kioto do Ramowej Konwencji Narodów Zjednoczonych w sprawie zmian klimatu, sporzadzony w Kioto dnia 11 grudnia 1997 r., Dz. U. 2005, nr 203, poz. 1684.

Ramowa konwencja Narodów Zjednoczonych w sprawie zmian klimatu, sporzadzona w Nowym Jorku dnia 9 maja 1992 r., Dz. U. 1996, nr 53, poz. 238.

Raport IEO: rozwój sektora OZE mógłby dać 77 tys. nowych miejsc pracy, https:// www.cire.pl/item,130120, 1,0,0,0,0,0,raport-ieo-rozwoj-sektora-oze-moglby -dac-77-tys-nowych-miejsc-pracy.html (dostęp: 21.02.2021).

Statystycznevademecumsamorzadowca-powiatpińczowskiw2019roku,https://kielce .stat.gov.pl/vademecum/vademecum_swietokrzyskie/portrety_powiatow/ Powiat\%20 pinczowski.pdf (dostęp: 21.02.2021).

Strategia rozwoju powiatu pińczowskiego, Pińczów 2015.

Szafrański A., Prawo energetyczne. Wartości i instrumenty ich realizacji, Warszawa 2014.

Uchwała Nr XXIII/168/2017 Rady Gminy Złota z dnia 30.05.2017 r. w sprawie przyjęcia Planu Gospodarki Niskoemisyjnej dla Gminy Złota, Załącznik 1; http://bip .gminazlota.pl/pliki/pgn_dla_gminy\% 20zlota.pdf (dostęp: 21.02.2021).

Uchwała Nr XXV/209/2016 Rady Miejskiej w Pińczowie z dnia 26.10.2016 r. wsprawie przyjęcia do realizacji Planu Gospodarki Niskoemisyjnej dla Gminy Pińczów, http://bip.gminy.com.pl/pinczow/pliki/01_Studium_ustalenia_tekstowe .pdf (dostęp: 21.02.2021).

Uchwała Nr XXVI/226/17 Rady Gminy Kije z dnia 10.05.2017 r. w sprawie przyjęcia Planu Gospodarki Niskoemisyjnej dla Gminy Kije, http://kije.biuletyn.net/ fls/bip_pliki/2020_08/BIPOLD003662/3662.pdf (dostęp: 21.02.2021).

Uchwała Nr XXVII/157/2016 Rady Gminy Michałów z dnia 25.11.2016 r. w sprawie przyjęcia Planu Gospodarki Niskoemisyjnej dla Gminy Michałów, https:// michalow.bip.gov.pl/uchwaly-2016r/sesja-z-dnia-25-listopada-2016-roku.html (dostęp: 21.02.2021).

Uchwała Nr XXXIII/153/2016 Rady Miejskiej w Działoszycach z dnia 21.12.2016 r. w sprawie przyjęcia Planu Gospodarki Niskoemisyjnej dla Gminy Działoszyce na lata 2016-2020, http://dzialoszyce.eobip.pl/_gAllery/60/88/6088/Uchwala_Nr_XXXIII-153-2016.pdf (dostęp: 21.02.2021).

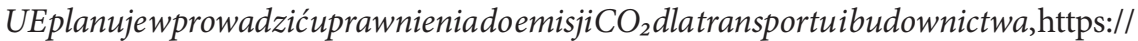
www.energetyka24.com/ue-planuje-wprowadzic-uprawnienia-do-emisji -co2-dla-transportu-i-budownictwa-komentarz (dostęp: 11.08.2021).

Ustawa z 5 czerwca 1998 r. o samorzadzie powiatowym, Dz. U. z 2020 r. poz. 920.

Ustawa z 5 czerwca 1998 r. o samorządzie województwa, Dz. U. z 2020 r. poz. 1668.

Ustawa z 8 marca 1990 r. o samorządzie gminnym, Dz. U. z 2020 r. poz. 713, 1378.

Wolska Z., Polityka Unii Europejskiej wobec zmian klimatycznych, „Studia Europejskie/Centrum Europejskie Uniwersytetu Warszawskiego” 2010, nr 3. 


\section{Ochrona powietrza i klimatu jako przedmiot wydatków inwestycyjnych gmin powiatu pińczowskiego}

\section{Streszczenie}

Artykuł skupia się na współcześnie gorąco dyskutowanym temacie ochrony powietrza i klimatu. Porusza problem istniejącej marginalizacji tej problematyki w wydatkach inwestycyjnych polskich gmin. Utrzymanie się takiej postawy wśród władz samorządowych stawia pod znakiem zapytania realizację w Polsce, deklarowanej przez kraje Unii Europejskiej do 2050 roku neutralności klimatycznej. Trudno będzie osiągnąć polskim władzom centralnym ten ambitny cel bez silniejszego jego zrozumienia ze strony samorządowców. Studium koncentruje się wokół inwestycji władz gminnych w ochronę powietrza i klimatu w jednym z uboższych w dochody regionów Polski centralnej, jakim pozostaje województwo świętokrzyskie. Uwaga pracy skupia się na gminach powiatu pińczowskiego w latach 2010-2018. Stara się ona wykazać, że na terenach, gdzie żyją niewielkie społeczności lokalne, inwestycje w ochronę powietrza i klimatu niejednokrotnie były dotąd marginalizowane. Co więcej, skala istniejącej tam luki inwestycyjnej w tym zakresie nie pozwoli na szybką transformację energetyczną. Analiza artykułu oparła się na wynikach analiz dokumentów lokalnych, sprawozdań finansowych i informacjach pochodzących ze statystyk publicznych.

Słowa kluczowe: niska emisja, wydatki lokalne, ochrona powietrza i klimatu, transformacja energetyczna, gospodarka niskoemisyjna

\section{Air and Climate Protection as the Subject of Investment Expenditures of Pińczów District Communes}

\section{Abstract}

Article focuse on the hotly discussed topic of air and climate protection. It addresses the problem of the existing marginalization of this issue in the investment expenditure of Polish municipalities. Maintenance of such an attitude of local authorities calls into question the implementation in Poland, as declared by the European Union countries by 2050 climate neutrality. It will be difficult for the Polish central government to achieve this ambitious goal without its stronger understanding on the part of local government officials. Study focuses on investments of municipal authorities in air and climate protection in one from the poorer regions of central Poland, which is the Świętokrzyskie Voivodeship. The work focuses on the communes of the Pińczów poviat in 2010-2018. It tries to show that in areas where small local communities live, investments in air and climate protection have often been marginalized. Moreover, the scale of the investment gap in this area will not allow for a quick energy transformation. The analysis of the article was based on the results of analyzes of local documents, financial statements and information from public statistics.

Keywords: low emission, local expenses, air and climate protection, energy transformation, low-emission economy 